Creative Commons User License: CC BY-NC-ND

Abstracted by: EBSCOhost, Electronic Journals Service (EJS),

Google Scholar, Journal Seek, Scientific Commons,

Food and Agricultural Organization (FAO), CABI and Scopus
Journal of Agricultural Extension

Vol. 24 (2) April, 2020

ISSN(e): 24086851; ISSN(Print); 1119944X

http://journal.aesonnigeria.org

http://www.ajol.info/index.php/jae

Email: editorinchief@aesonnigeria.org

\title{
Factors Affecting Rice Farming Practices among Farmers in Ogun and Niger States, Nigeria
}

https://dx.doi.org/10.4314/iae.v24i2.10

\section{Omoare, Ayodeji Motunrayo}

Department of Agricultural Education, Federal College of Education, Abeokuta, Nigeria

Email: ayodejiomoare@gmail.com; Tel.: +2348034741976

\section{Oyediran, Wasiu Oyeleke}

Department of Agricultural Extension and Rural Development, Federal University of

Agriculture, Abeokuta, Nigeria

Email: oyediran_wasiu@yahoo.com, Tel.: +2348053171938

\section{Abstract}

The study examined factors affecting rice farming practices of rural farmers in Ogun and Niger States, Nigeria. Three hundred and twenty respondents were selected through multistage sampling procedure. Frequency distribution, percentages and mean, student's $t$-test and regression analysis were used for data. All analysis was done at $5 \%$ level of significance. There was a significant difference in the farm practices of the rice farmers in Niger and Ogun States $(t=8.39, p \leq 0.05)$. Factor affecting rice farming practices was determinants of rice production output $(\beta=-0.13, p \leq 0.05)$. There was difference in the farming practices of rice farmers in Ogun and Niger States. Agricultural extension services, particularly, in Ogun State should expedite action in organizing training that can facilitate adoption of better farming practices in order to increase rice production and income generation for the rice farmers, while government and input suppliers should make fertilizers available and affordable.

Keywords: factors affecting farming practices; rice production; rural rice farmers;

\section{Introduction}

In Nigeria, rice production has been declining due to poor farm practices. Yet, the consumption of rice is increasing while the country continues to import rice to cater for the citizenry (Goronyo, 2019). Nigeria has been a major consumer and importer of rice in Africa (Maji, Bashir, Odoba, Gbanguba and Audu, 2015). Rice is the most important cereal and it is widely consumed in urban and rural areas (Omoare, 2016); it is one of the few food items whose consumption has no cultural, religious, ethnic or geographical boundary (Ibitoye, Idoko and Shaib, 2014). It is relatively easy to produce and is grown for sale and home consumption. In developed countries, production, processing, marketing, and consumption of rice have moved towards high-value food products. It is very important to note that despite the development of technology-driven farming system across the world, rice value chain in Nigeria is not yet developed to meet local and international market requirements as limited value 
Creative Commons User License: CC BY-NC-ND

Abstracted by: EBSCOhost, Electronic Journals Service (EJS),

Google Scholar, Journal Seek, Scientific Commons,

Food and Agricultural Organization (FAO), CABI and Scopus
Journal of Agricultural Extension

Vol. 24 (2) April, 2020

ISSN(e): 24086851; ISSN(Print); 1119944X

http://journal.aesonnigeria.org

http://www.ajol.info/index.php/iae

Email: editorinchief@aesonnigeria.org

addition (if any) is done to the rice, making its acceptability limited to rural markets (Osabuohien, Okorie and Osabohien, 2018). According to Humphrey and Robinson (2015), value chain is the full range of activities required to bring a product or service from conception, through the different phases of production, delivery to final consumers and final disposal after use. The actors in the rice value chain could be categorized based on their activities such as production which is mostly the rural farmers and support services, processing which is a combination of parboiling and milling, and marketing which is mostly by the women Ayedun and Adeniyi (2019). This study focused on production stage which is principally farming and it is the first and paramount stage in rice value chain (RVC).

Nigeria has ecologies that favour rain-fed lowland, irrigated lowland as well as upland rice production. Production is dominated by smallholder farmers who use rudimentary technology and traditional method in producing over $80 \%$ of our national production. Rice grows very well in almost every part of the country (Omoare, 2016). Report on rice production has shown an average increase of 300,000 tonnes in the 1990s to over 4 million tonnes in the year 2019 (FAOSTAT, 2015; Roy-Macauley, 2019). According to Federal Ministry of Agriculture and Rural Development (2012) and Goronyo (2019), Nigeria currently produces about 8million tonnes yearly, but can produce 14 million tonnes per year if appropriate farming practices are put in place. The dominant rice exporters to Nigeria, India and Thailand, indicated a paltry exportation of 426 tonnes rice as at July 2018 which is a long walk away from the over 400,000 metric tonnes of rice previously imported into the country (RoyMacauley, 2019). This marginal decline in rice importation is attributed to the recent pronouncement by the Federal Government on border closure. Prior to the closure of land borders rice importation is seen as a waste of foreign exchange based on the comparative advantage of the country in rice production (Oyediran, 2016).

As at 2019, the country is still insufficient in rice production (Roy-Macauley, 2019). Total potential land for irrigated rice production is estimated at 1.6 million hectares out of which only 47,798ha are available (FAOSTAT, 2015) whereas in the last decade rice consumption has increased at an annual average rate of $10.3 \%$ (Maji et al., 2015). It is expected to increase further due to increase in population and urbanization. On one side, rice became a critical component of the Nigerian household diet and on the other side, a major consumer of the country's foreign exchange. It is indeed lamentable for a country such as Nigeria with huge human and natural resources (land and water), including capital to continue to bear the burden of unbearable pain of rice importation for many decades following huge capital flight and increasing unemployment (Akinwunmi, 2013). The current rate of rice importation gives serious concern as the nation population grows. In recent time, 
Creative Commons User License: CC BY-NC-ND

Abstracted by: EBSCOhost, Electronic Journals Service (EJS),

Google Scholar, Journal Seek, Scientific Commons,

Food and Agricultural Organization (FAO), CABI and Scopus
Journal of Agricultural Extension

Vol. 24 (2) April, 2020

ISSN(e): 24086851; ISSN(Print); 1119944X

http://journal.aesonnigeria.org

http://www.ajol.info/index.php/jae

Email: editorinchief@aesonnigeria.org

a bag of $50 \mathrm{~kg}$ rice is sold for as high as $\$ 17,000$ - $\$ 19,000$ in the local markets hence making it non-affordable for most low income households. There are up-land rice, low-land rice, Fadama rice, all types of rice that grow very well in Sokoto, Kebbi, Kano, Katsina, Niger, Kogi, Ogun, Enugu and Delta States yet Nigeria government has not harnessed these potentials to boost local rice production; meanwhile local rice is more nutritious than the imported ones where most of the nutrients have been washed off during processing (Akinwumi, 2013).

Over the years, farmers cultivate different varieties of rice such as Ofada, Nerica 8 and Faro 44 using different farming practices to overcome the problems of declining rice yield. Though recent news indicated that rice production in Nigeria has overtaken that of Egypt, the reality is that supply has not met the demand, the evidence is that it is very difficult for consumers to get required quantity from the markets. Even at that, the local rice production and supply continuously declining in the southern parts of the country compared to the northern parts thereby aggravating problem of food insecurity. It is on this premise that this study examined factors affecting farm practices of rural farmers in rice production from a state in southern Nigeria (Ogun State) and another state from northern parts (Niger State) with the view to compare the prevailing farming practices. This will help to improve farming practices and enhance productivity of rice farmers across the country.

\section{The specific objectives of this study were to:}

i. assess farming practices for rice production in Ogun and Niger States;

ii. estimate the production output of the rice; and

iii. identify factors affecting rice farming practices.

\section{Hypotheses of the Study}

$\mathrm{H}_{01}$ : There is no significant relationship between factors affecting rice farming practices and production output.

$\mathrm{H}_{02}$ : There is no significant difference in the farming practices of rice farmers in Ogun and Niger States.

\section{Methodology}

This study was carried out in Ogun and Niger States, Nigeria. Ogun State lies between the latitudes $7^{0} 18^{\prime} \mathrm{N}$ and longitude $5^{0} 55^{\prime} \mathrm{E}$ while Niger State lies between latitudes $11^{\circ} 30^{\prime} \mathrm{N}$ and longitudes $7^{\circ} 20^{\prime} \mathrm{E}$. Multistage sampling techniques were used to select 320 rice farmers for this study. Two local government areas (LGAs) were purposively selected in Ogun and Niger States based on the a priori information that they have large rice producing town-communities. This gave rise to four LGAs, 
Creative Commons User License: CC BY-NC-ND

Abstracted by: EBSCOhost, Electronic Journals Service (EJS),

Google Scholar, Journal Seek, Scientific Commons,

Food and Agricultural Organization (FAO), CABI and Scopus
Journal of Agricultural Extension

Vol. 24 (2) April, 2020

ISSN(e): 24086851; ISSN(Print); 1119944X

http://journal.aesonnigeria.org

http://www.ajol.info/index.php/iae

Email: editorinchief@aesonnigeria.org

namely: Yewa North and Obafemi-Owode in Ogun State and Lavun and Gbako LGAs in Niger State. Secondly, two rice farming town-communities each from the four selected rice producing LGAs from the 2 States were purposively selected, this gave rise to 8 communities namely Eegua, Igbogila, Obafe, Ofada in Ogun State, while Ebba, Baddegi, Lemu Kataeregi in Niger State. In the third stage, simple random sampling technique was used to select 40 registered rice farmers each from these communities (list of 3,197 farmers that participated in the Growth Enhancement Support Scheme (GESS) in the two states was used). This gave rise to a total of 320 rice famers which was used as the sample size for this study.

Data for this study were collected through the use of a well-structured interview guide in addition to focus group discussions (FGD) conducted with rice farmers in the study areas. The exercise was carried out with the assistance of Ogun State Agricultural Development Programme (OGADEP) and Niger State Agricultural Development Programme (NSADP) field officers and also the executive members of rice farmers' association (RIFAN), who helped to locate farm locations. The instrument used for the data collection was subjected to face and content validity involving supervisors' assessment, experts in agricultural extension and rural development and agricultural administration. Their criticisms and suggestions were positively utilized for a more valid instrument. Content validity was carried out by the Agricultural Extension Experts; various constructs and measurements were thoroughly checked to ensure that the instrument covers all the objectives highlighted in this study. Also, the reliability test was conducted using test re-test method. Administration of the instrument was done for 40 rice farmers (20 farmers in each state) who were not included in the actual study sample at two weeks' interval. Scores were assigned to the responses of the selected respondents. Total scores for each period were computed and the Pearson Product Moment Correlation (PPMC) was used to determine the relationship coefficient between the two set of scores.

Age, household size, farmers experience and farm size were measured as actual number as at the time of data collection while gender, marital status and farming status were nominally measured by assigning numbers. Educational attainment was measured in order of $0,1,2$ and 3 for no formal education, primary education, secondary education and tertiary education, respectively. Methods for weed and birds control were operationalized as Used (1), Not Used (0). Harvested rice was measured in tonnes/ha while sale was measured in $\$ /$ ha at rato level. Constraints were also nominally measured as Yes (1), No (0). Data obtained were analysed with percentage, t-test and linear regression analysis at $p \leq 0.05$ level of significance. The Linear Regression equation is $Q=f(p)$ where $Q$ is production output and $p$ represents problems in the rice farming. 
Creative Commons User License: CC BY-NC-ND

Abstracted by: EBSCOhost, Electronic Journals Service (EJS),

Google Scholar, Journal Seek, Scientific Commons,

Food and Agricultural Organization (FAO), CABI and Scopus
Journal of Agricultural Extension

Vol. 24 (2) April, 2020

ISSN(e): 24086851; ISSN(Print); 1119944X

http://journal.aesonnigeria.org

http://www.ajol.info/index.php/iae

Email: editorinchief@aesonnigeria.org

Thus the explicit model is:

Linear: $Q=\alpha+\beta_{1} P_{1}+\beta_{2} X_{2}+\beta_{3} P_{3}+\beta_{4} P_{4}+\beta_{5} P_{5} \ldots \ldots+\beta_{n} P_{n}+$ ei

Where;

$\mathrm{Q}=$ Production output $(\mathrm{kg} / \mathrm{ha})$;

$P_{1}=$ Inadequate finance (scores);

$\mathrm{P}_{2}=$ Pest and diseases incidence (scores);

$\mathrm{P}_{3}=$ Climate change (scores);

$\mathrm{P}_{4}=$ Land tenure problem (scores);

$\mathrm{P}_{5}=$ Birds disturbance (scores)

$P_{6}=$ Land degradation and poor soil fertility;

$\mathrm{P}_{7}=$ Non-availability of quality seeds and agro-chemicals (scores);

$\mathrm{P}_{8}=$ Lack of rural infrastructure (scores);

$\mathrm{P}_{9}=$ Inadequate agricultural extension support on training and capacity building (scores);

$\mathrm{P}_{10}=$ High cost of fertilizers (scores);

$\alpha=$ Constant; and

ei $=$ error term

\section{Results and Discussion}

\section{Rice Farming Practices in Ogun and Niger States}

From the results in Table 1, more than ninety percent of the respondents practiced lowland rice farming system (93.7\%) while $53.8 \%$ engaged in upland rice farming system but cultivation of upland rice is more (64.4\%) in Niger State than Ogun State (43.1\%). Meanwhile, those cultivated lowland rice was a bit higher (96.3\%) in Ogun State than Niger State $(91.2 \%)$. It shows that lowland rice farming system is dominant in north and south, Nigeria, and this could be attributed to presence of rivers, ponds and streams in every part of the country. Weed control is done by applying herbicides (100\%) but $36.6 \%$ of the respondents did hand weeding on their rice farms. The use of herbicides in recent time is due to its availability, cheaper price, convenience and effectiveness when it compares to the hiring of labour for weed control. Still, $46.8 \%$ of the respondents did hand weeding in Ogun State compared to $26.3 \%$ in Niger State. This is possible because of varying vegetation; north is savannah with light vegetation while south is rainforest with thick vegetation. The quantity of herbicides used by $64.7 \%$ of the respondents were $3.0-5.0$ litres/ha while $35.3 \%$ sprayed more than 6.0 litres/ha to control weeds. Similarly, $52.5 \%$ applied NPK fertilizer to rice farm in Niger State while it was only very few $(21.2 \%)$ that applied NPK in Ogun State. Fertilizer application was relatively low for both Urea $(55 \%)$ and NPK (36.9\%) in the sampled states. The use of Urea fertilizer was higher $(68.1 \%)$ in Niger State than Ogun State (41.9\%). Also, $86.9 \%$ of respondents in Ogun State and $65.6 \%$ in Niger State applied more than 4.0 litres of insecticides per hectare. The higher rate of insecticides used among respondents in Ogun State is as a result of climatic condition that support rapid spread of insects in the state. Since 1950s the use of chemical insecticides and pesticides has been dominating plant protection techniques in Ogun State (Abdulsalam-Saghir and Banmeke, 2015). Nets $(100 \%)$ and trap (25\%) were used for birds and rodents control but no respondents 
Creative Commons User License: CC BY-NC-ND

Abstracted by: EBSCOhost, Electronic Journals Service (EJS), Google Scholar, Journal Seek, Scientific Commons,

Food and Agricultural Organization (FAO), CABI and Scopus

http://eoi.citefactor.org/10.11226/v24i2
Journal of Agricultural Extension

Vol. 24 (2) April, 2020

ISSN(e): 24086851; ISSN(Print); 1119944X

http://journal.aesonnigeria.org

http://www.ajol.info/index.php/iae

Email: editorinchief@aesonnigeria.org

used clapper in the sampled states. Rice farmers adduced reason for not using clapper to the high cost to purchase and maintenance on the farm. Most (80\%) of the respondents used drill irrigation while $11.9 \%$ used watering-can. Niger State had higher proportion (91.3\%) of respondents that used drill irrigation as against $70 \%$ in Ogun State. Irrigation farming was a common practice in the north because of prolonged dry season compared to the wet season in the south. It can be said that apart from the weed control that is similar in both states, the use of herbicides, fertilizers and irrigation system are differed. This is a pointer to the fact that rice farming practices in Niger State is better than that of Ogun State. Previous findings by Ojo and Ogunyemi (2013) and Yusuf, Salau and Girei (2019) showed that access and adoption of improved agronomic practices resulted in increased farm output.

Table 1: Rice farming practices in Ogun and Niger States

\begin{tabular}{|c|c|c|c|}
\hline Farming practices & Ogun (\%) & Niger (\%) & Total (\%) \\
\hline \multicolumn{4}{|l|}{ Farmina system } \\
\hline Upland rice farming & 43.1 & 64.4 & 53.8 \\
\hline Lowland rice farming & 96.3 & 91.2 & 93.7 \\
\hline \multicolumn{4}{|l|}{ Weed control system } \\
\hline Hand weeding & 46.8 & 26.3 & 36.6 \\
\hline Use of herbicides & 100.0 & 100.0 & 100.0 \\
\hline \multicolumn{4}{|c|}{ Use of herbicides (Litres/ha) } \\
\hline $3.0-5.0$ & 66.9 & 62.5 & 64.7 \\
\hline 6.0 and above & 33.1 & 37.5 & 35.3 \\
\hline \multicolumn{4}{|c|}{ Use of Fertilizer (kg/ha) } \\
\hline Urea & 41.9 & 68.1 & 55.0 \\
\hline NPK & 21.2 & 52.5 & 36.9 \\
\hline \multicolumn{4}{|c|}{$\begin{array}{l}\text { Disease and insect control } \\
\text { Cost of insecticides/fungicides } \\
\text { ( } \$ \text { /ha) }\end{array}$} \\
\hline $1,000-2,000$ & 13.1 & 34.4 & 23.8 \\
\hline 2,500 and above & 86.9 & 65.6 & 76.3 \\
\hline \multicolumn{4}{|c|}{ Birds and rodents control } \\
\hline Use of trap & 30.6 & 19.4 & 25.0 \\
\hline Nets & 100.0 & 100.0 & 100.0 \\
\hline Clapper & 0.0 & 0.0 & 0.0 \\
\hline \multicolumn{4}{|l|}{ Irrigation system } \\
\hline Knapsack & 0.0 & 0.0 & 0.0 \\
\hline Drill & 70.0 & 91.3 & 80.0 \\
\hline Sprinkler & 0.0 & 0.0 & 0.0 \\
\hline Watery-can & 15.6 & 8.1 & 11.9 \\
\hline
\end{tabular}

Source: Field Survey, 2019.

*multiple responses recorded 
Creative Commons User License: CC BY-NC-ND

Abstracted by: EBSCOhost, Electronic Journals Service (EJS), Google Scholar, Journal Seek, Scientific Commons,

Food and Agricultural Organization (FAO), CABI and Scopus
Journal of Agricultural Extension

Vol. 24 (2) April, 2020

ISSN(e): 24086851; ISSN(Print); 1119944X

http://journal.aesonnigeria.org

http://www.ajol.info/index.php/jae

Email: editorinchief@aesonnigeria.org

\section{Production Output of Rice}

Results in Table 2 show that $63.2 \%$ harvested more than 1.5 tonnes/ha while $26.2 \%$ harvested $1.0-4.0$ tonnes/ha. Based on the state, $70.6 \%$ of respondents in Niger State got higher harvest than their counterparts rice farmers from Ogun State $(55.6 \%)$. The fact is that the majority of rice farmers from Niger State applied Urea and NPK fertilizers to boost rice yield whereas use of fertilizers is not a popular practice in Ogun State. From the sales of rice, $35.9 \%$ realized less than $\$ 500,000 /$ ha, $32.8 \%$ generated $\$ 501,000-600,000 /$ ha and $20 \%$ got $\$ 601,000-$ $700,000 /$ ha. This is an indication that rice farmers from both states generated appreciable income from harvested rice which forms part of their livelihood; the money will go a long way to take care of the basic needs of their households. According to Ayedun and Adeniyi (2019), rice production is a profitable enterprise going by the high demand of rice grains in the market. Similar findings by Yusuf et al. (2019) revealed that the current annual income from rice production in Niger State is as a result of adoption of improved rice farming practices introduced by Agricultural Research Outreach Centres (AROCs).

Table 2: Production output and sales of rice farmers in Ogun and Niger States

\begin{tabular}{llll}
\hline Rice produced & Ogun (\%) & Niger (\%) & Total (\%) \\
\hline Harvesting (tonnes/ha) & & & \\
$0.5-0.9$ & 5.0 & 9.3 & 7.2 \\
$1.0-1.4$ & 33.1 & 20.0 & 26.2 \\
1.5 and above & 55.6 & 70.6 & 63.2 \\
Sales (\$/ha) & & & \\
Less than 500,000 & 38.8 & 33.1 & 35.9 \\
$501,000-600,000$ & 34.4 & 31.2 & 32.8 \\
$601,000-700,000$ & 18.1 & 21.9 & 20.0 \\
701,000 and above & 8.7 & 13.8 & 11.3 \\
\hline
\end{tabular}

Source: Field Survey, 2019.

\section{Factors Affecting Rice Farming Practices in Ogun and Niger States}

From the results in Table 3, most of the respondents identified birds' disturbance $(96.6 \%)$, high cost of fertilizers $(92.5 \%)$, inadequate finance $(83.1 \%)$ and lack of rural infrastructure $(82.8 \%)$ as major impediments to the rice farming in the sampled states and these were ranked $1^{\text {st }}, 2^{\text {nd }}, 3^{\text {rd }}$ and $4^{\text {th }}$, respectively. In Niger State for instance, $98.7 \%$ of the respondents indicated birds' disturbance compared to $94.4 \%$ in Ogun State. Equally, Niger State reported higher burden of finance $(84.4 \%)$ and high cost of fertilizers (93.9\%) compared to $81.9 \%$ and $91.3 \%$ in Ogun State, respectively. This is in tandem with the report of Akinwunmi (2013) that corruptionridden fertilizer distribution system affects rice production in Nigeria. Paradoxically, Ogun State had higher incidence of pest and diseases (86.3\%) and it is due to high 
Creative Commons User License: CC BY-NC-ND

Abstracted by: EBSCOhost, Electronic Journals Service (EJS), Google Scholar, Journal Seek, Scientific Commons,

Food and Agricultural Organization (FAO), CABI and Scopus
Journal of Agricultural Extension

Vol. 24 (2) April, 2020

ISSN(e): 24086851; ISSN(Print); 1119944X

http://journal.aesonnigeria.org

http://www.ajol.info/index.php/jae

Email: editorinchief@aesonnigeria.org

relative humidity in the rainforest region whereas $76.3 \%$ reported problem of Niger State pest and diseases. Also, effects of climate change (80.6\%) and land tenure system (87.5\%) were more serious in Ogun State than Niger State with $78.1 \%$ and $67.5 \%$, respectively. Land degradation and poor soil fertility, inadequate agricultural extension support on training and capacity building and non-availability of quality seeds and agro-chemicals were ranked $8^{\text {th }}, 9^{\text {th }}$, and $10^{\text {th }}$, respectively as major factors affecting rice farming practices in the sampled states. The problem of land degradation and poor soil fertility is more pronounced in Niger State $(80.6 \%)$ than Ogun State $(71.9 \%)$. Extension support posed a major problem to rice farmers in Ogun State $(90 \%)$ than Niger State $(61.8 \%)$. The implication is that large proportion of rice farmers in Niger State has access to information and training through extension agents than their counterparts in Ogun State. It can be inferred from these findings that rice farmers in the south are confronted with problems of land tenure system, pest and diseases incidence, and inadequate agricultural extension support and these are factors limiting rice productivity and farmers' profit in the south compare to the north. Also, these problems have limited rice farmers in the south to small scale while their counterparts from the north cultivated rice on medium to large scale. This is similar to the findings of Sodiya and Oyediran (2014) that most rural farmers in the south operate at subsistence level.

Table 3: Factors affecting rice farming practices in Ogun and Niger States \begin{tabular}{lllll}
\hline Factors Affecting Rice Production & Ogun (\%) & Niger & Total (\%) & Rank
\end{tabular}

(\%)

Birds disturbance
High cost of fertilizers
Inadequate finance
Lack of rural infrastructure
Pest and diseases incidence
Climate change
Land tenure problem
Land degradation and poor soil fertility
Inadequate agricultural extension
support on training and capacity
building

Non-availability of quality seeds and 65.6

94.4

91.3

81.9

78.1

86.3

80.6

87.5

71.9

90.0

agro-chemicals

Source: Field Survey, 2019.

*multiple responses recorded

\section{Difference in Farming Practices of Rice Farmers in Ogun and Niger States}

Results of the t-test in Table 4 show that significant difference existed in the farming practices of the rice farmers in Ogun and Niger States $(t=8.39, p=0.001)$. It implies 
Creative Commons User License: CC BY-NC-ND

Abstracted by: EBSCOhost, Electronic Journals Service (EJS), Google Scholar, Journal Seek, Scientific Commons,

Food and Agricultural Organization (FAO), CABI and Scopus
Journal of Agricultural Extension

Vol. 24 (2) April, 2020

ISSN(e): 24086851; ISSN(Print); 1119944X

http://journal.aesonnigeria.org

http://www.ajol.info/index.php/jae

Email: editorinchief@aesonnigeria.org

that farming practices in Ogun and Niger States are different. This could be connected to the fact that weather condition and vegetation in the north support production of cereal crops such as maize, sorghum, millet and rice, and as such these influence their farming practices. Most of the rice produced in the north is from lowland while upland rice farming is common practice in the south. Also, rice farmers in the north applied fertilizers and organic manures, and used irrigation system which resulted in higher productivity compared to the non-use of fertilizers and irrigation in the south. In addition, National Cereals Research Institute (NCRI), Badeggi provides seeds and training support to the rice farmers in Niger State. On this premise, the farming practices in Niger State differ from that of Ogun State; if farmers adopt and apply improved farming practices there would be high productivity. Yusuf et al. (2019) found that adoption of improved agricultural technologies and modern farming techniques are instruments of increased productivity and food security; improved farming practices also have potentials of increasing income

Table 4: Difference between farming practices in Ogun and Niger States

\begin{tabular}{llllll}
\hline $\begin{array}{l}\text { Sampled } \\
\text { States }\end{array}$ & $\begin{array}{l}\text { Sample } \\
\text { size }\end{array}$ & Mean & $\begin{array}{l}\text { Std. } \\
\text { Dev. }\end{array}$ & Mean diff. & t \\
\hline Ogun & 160 & 1.69 & 0.11 & 1.16 & $8.39^{*}$ \\
Niger & 160 & 0.53 & 0.13 & & \\
\hline
\end{tabular}

Significant at ${ }^{*} p \leq 0.05$

Source: Field Survey, 2019

\section{Factors Affecting Rice Production Output}

Table 5 shows that inadequate finance $(\beta=-0.13)$, pest and diseases incidence $(\beta=$ $-0.24)$, climate change $(\beta=-0.26)$, land tenure problem $(\beta=0.10)$, birds disturbance $(\beta=-0.13)$, land degradation and poor soil fertility $(\beta=0.13)$, non-availability of quality seeds and agro-chemicals $(\beta=0.11)$ and high cost of fertilizers $(\beta=-0.12)$ were significant to production output. The negative signs of coefficients however indicate an inverse relationship between the factors affecting rice farming practices and production output of rice, that is, the more severe the problems the lesser the rice produced. For instance, the implication of pest and diseases incidence on rice output is that for every $1 \%$ increase in the problem, rice production would reduce by $24 \%$; likewise, climate change $26 \%$, birds' disturbance $13 \%$ and fertilizers $12 \%$. Ayedun and Adeniyi (2019) reported that fertilizer shifts production frontier upwards and enhance higher productivity. Though, inadequate agricultural extension support on training and capacity $(\beta=-0.01)$ and lack of rural infrastructure $(\beta=-0.04)$ were not significant to production output of rice the coefficients were negative. It means that poor extension service and rural infrastructure affected rice production. The significant of $F$-value $(F=39.85)$ at $p<0.05$ affirmed the relationship between factors affecting rice farming practices and production output of rice in the sampled 
Creative Commons User License: CC BY-NC-ND

Abstracted by: EBSCOhost, Electronic Journals Service (EJS), Google Scholar, Journal Seek, Scientific Commons,

Food and Agricultural Organization (FAO), CABI and Scopus

http://eoi.citefactor.org/10.11226/v24i2
Journal of Agricultural Extension

Vol. 24 (2) April, 2020

ISSN(e): 24086851; ISSN(Print); 1119944X

http://journal.aesonnigeria.org

http://www.ajol.info/index.php/jae

Email: editorinchief@aesonnigeria.org

states. By these findings, it can be inferred that the militating factors seriously undermined rice production in the study areas.

Table 5: Factors affecting rice production output

\begin{tabular}{lllll}
\hline Constraints & $\boldsymbol{\beta}$ & $\begin{array}{l}\text { Std. } \\
\text { Error }\end{array}$ & Beta & T \\
\hline (Constant) & 70.91 & 4.34 & & 16.36 \\
Inadequate finance & -1.27 & 0.41 & -0.13 & $-3.09^{*}$ \\
Pest and diseases incidence & -2.46 & 0.35 & -0.24 & $-6.99^{*}$ \\
Climate change & -2.25 & 0.41 & -0.26 & $-5.53^{*}$ \\
Land tenure problem & 1.09 & 0.52 & 0.10 & $2.10^{*}$ \\
Birds disturbance & -0.97 & 0.47 & -0.13 & $-2.06^{*}$ \\
Land degradation and poor soil fertility & -1.16 & 0.40 & 0.13 & $-2.90^{*}$ \\
Non-availability of quality seeds and & -1.57 & 0.58 & 0.11 & $-2.69^{*}$ \\
agro-chemicals & & & & \\
Lack of rural infrastructure & -0.51 & 0.51 & -0.04 & -0.99 \\
Inadequate agricultural extension & -0.08 & 0.58 & -0.01 & -0.13 \\
support on training and capacity & & & & \\
building & & & & \\
High cost of fertilizers & -1.57 & 0.61 & -0.12 & $-2.56^{*}$ \\
& & & & \\
$R^{2}$ & 0.69 & & & \\
Adjusted R & 0.67 & & & \\
F-value & 39.85 & & & \\
\hline${ }^{2}$ P 0.05 & & & & \\
\hline
\end{tabular}

${ }^{*} \mathrm{P} \leq 0.05$

Source: Field Survey, 2019

\section{Conclusion and Recommendations}

Differences existed in the farming practices of rice farmers in Ogun State (south) and Niger State (north) of Nigeria. Major factors affecting farming practices and production output of rice in the states were birds' disturbance, high cost of fertilizers, and inadequate financial support. Farmers should form a cluster to purchase a big clapper and device other indigenous means to scare the birds away; government and input supplies should made fertilizers available and affordable to the rice farmers; rice farmers should use their association platform (the Rice Farmers Association of Nigeria) to acquire credits from banks of agriculture; and agricultural extension services should expedite action by organizing training that can facilitate adoption of better farming practices in order to increase rice production and income generation for the farmers in the study areas. 
Creative Commons User License: CC BY-NC-ND

Abstracted by: EBSCOhost, Electronic Journals Service (EJS), Google Scholar, Journal Seek, Scientific Commons,

Food and Agricultural Organization (FAO), CABI and Scopus
Journal of Agricultural Extension

Vol. 24 (2) April, 2020

ISSN(e): 24086851; ISSN(Print); 1119944X

http://journal.aesonnigeria.org

http://www.ajol.info/index.php/iae

Email: editorinchief@aesonnigeria.org

http://eoi.citefactor.org/10.11226/v24i2

\section{References}

Abdulsalam-Saghir, P. B. and Banmeke, T. O. A. (2015). Enhancing sustainable environmental management through indigenous pest and diseases control practices by Ofada rice growers in Ogun State, Nigeria. Journal of Agricultural Extension and Rural Development, 7(3): 80 - 86.

Akinwumi, A. (2013). Rice consumption and importation in Nigeria, no solution in sight. http://www.vanguardngr.com/2013/12/rice-consumption-importation-nigeria-solutionsight/. Accessed on Thursday $15^{\text {th }}$ December, 2019.

Ayedun, B. and Adeniyi, A. (2019). Determinants of rice production of small-scale farmers in mono-cropping and intercropping systems in Nigeria. Acta Scientific Nutritional Health, 3(7): 75-85.

Cadoni P., and Angelucci F., (2013). Analysis of incentives and disincentives for Rice in Nigeria. Technical notes series, MAFAP, FAO, Rome.

Food and Agriculture Organization of United States, (2015). FAOSTAT Country Selection. [Online] http://FAOstat3.FAO.org/home/index.html\#DOWNLOAD. Assessed $26^{\text {th }}$ May, 2018.

Federal Ministry of Agriculture and Rural Development, (2012). Agricultural Transformation Agenda: Repositioning Agriculture to drive Nigeria's Economy.

Goronyo, A. (2019). Nigeria now produces $8 \mathrm{~m}$ metric tonnes of rice yearly, as Central Bank of Nigeria (CBN) disburses N40bn to Rice Farmers Association of Nigeria (RIFAN). 21 May, 2019. Pulse Nigeria. www.pulse.ng.

Humphrey, J., and Robinson, E. (2015). Markets for Nutrient-rich Foods: Policy Synthesis from Three Country Studies IDS Evidence Report 161. Institute of Development Studies, Brighton.

Ibitoye, S. J., Idoko, D., Shaibu, U. M. (2014). Economic assessment of rice processing in Bassa Local Government Area Of Kogi State, Nigeria. Asian Journal of Basic and Applied Sciences, 1(2): 8-17.

Niger State, Online Nigeria. Community Portal of Nigeria, 2003. http://www.onlinenigeria.com/links/nigeradv.asp? blurb=335.

National Population Census. (2006). Legal Notice of Publication of 2006 Census Final Result. Federal Republic of Nigeria Official gazette: Federal Capital Territory Abuja.

Maji, A. T., Bashir, M., Odoba, A., Gbanguba, A. U., Audu, S. D. (2015). Genotype X Environmental Interaction and Stability Estimates for Grain Yield of Upland Rice Genotypes in Nigeria. Journal of Rice Res. 3(2): 1-5. http:/dx.doi.org/10.4172/23754338.1000136.

Ojo, S. O., and Ogunyemi, A. J. (2013). Analysis of factors influencing the adoption of improved cassava production technology in Ekiti State, Nigeria. International Journal of Agriculture Science and Natural Science, 1(3):40-44.

Omoare, A. M. (2016). Production of Ofada Rice (oryza spp) for Sustenance in Obafemi Owode Local Government Area of Ogun State, Nigeria. In Multidisciplinary Journal of Research and Methods in Tertiary Education, 2(2): 301-314.

Osabuohien, E., Okorie, U. and Osabohien, R. (2018). Rice Production and Processing in Ogun State, Nigeria: Qualitative Insights from Farmers' Association. In Obayelu, E. (Eds). Food Systems Sustainability and Environmental Policies in Modern Economics, pp.188-215. Hershey, PA: IGI Global.DOI:10.4018/978-1-5225-36314.ch009.

Oyediran, W. O. (2016). Assessment of Paddy Rice (Ofada) Processing in ensuring rural women livelihood sustainability in Ogun State, Nigeria. International Journal for Research in Agricultural Research, 2(2): 59 - 70. 
Creative Commons User License: CC BY-NC-ND

Abstracted by: EBSCOhost, Electronic Journals Service (EJS),

Google Scholar, Journal Seek, Scientific Commons,

Food and Agricultural Organization (FAO), CABI and Scopus

http://eoi.citefactor.org/10.11226/v24i2
Journal of Agricultural Extension

Vol. 24 (2) April, 2020

ISSN(e): 24086851; ISSN(Print); 1119944X

http://journal.aesonnigeria.org

http://www.ajol.info/index.php/iae

Email: editorinchief@aesonnigeria.org

Roy-Macauley, H. (2019). So, Nigeria is now the Highest Rice Producer in Africa? Thisday Newspaper. March 12, 2019.

Sodiya, C. I. and Oyediran, W. O. (2014). Contributions of melon production to livelihood sustainability of rural farming households in Oyo State, Nigeria. Journal of Biology, Agriculture and Healthcare, 4 (12): 8 - 18.

Yusuf, N., Salau, E., and Girei, A. A. (2019). Determinants of adoption rate of rice production technologies introduced by agricultural research outreach centres (AROCs) by farmers in Niger State, Nigeria. Asian Journal of Agricultural Extension, Economics and Sociology, 35(1): 1-11. https://doi.org/10.9734/ajaees/2019/v35i130215, 